vesicoureteric reflux. As the abnormality was visible on the excretion urogram, stasis is the probable explanation. In patients with true vesicoureteric reflux this is normally only seen on micturating cystourethrography. Unfortunately none of our patients underwent this procedure, which would probably have elucidated the cause. Evidence from animal experiments shows maximum ureteric pressures of about $60-80 \mathrm{~cm} \mathrm{H}_{2} \mathrm{O}$ at the peak of a peristaltic wave. ${ }^{+}$If such levels are attained in the human ureter high-pressure filling would probably lead to obstruction at the vesicoureteric junction.

The postoperative results in this study show the range of responses to surgery of patients with chronic retention. Patients with low-pressure filling and inadequate detrusor contraction during voiding respond least well. After prostatic surgery they still complain of a slow stream, hesitancy, and a feeling of incomplete emptying. When closely questioned they also often admit to having to strain to void. Their postoperative symptoms, however, suggest residual obstruction. If urodynamic investigations are not used to investigate postprostatectomy symptoms such as these persistent obstruction may be diagnosed. In a previous study several such patients were seen. Some had a second operation, which invariably failed to help them and in five cases led to the development of stress incontinence, presumably due to impairment of the continence mechanisms at and immediately proximal to the external sphincter.

Several operations that aim to improve bladder emptying by decreasing bladder volume-namely, partial cystectomy, vesicoplication, and cystoplasty-have been described '- ' but have been little used in our area. Vesicoplication yields disappointing results and is now rarely performed. Urodynamic studies after vesicoplication in six patients showed a persistently high residual urine and little change in the symptoms.

This study has served to define the types of chronic retention found in men and show that urodynamic investigations predict which patients are likely to benefit from prostatectomy. Postoperative urodynamic studies indicate whether the obstruction has been relieved or still persists; they may also explain any persistent postoperative symptoms the patient might have and indicate whether further surgical intervention is warranted.

\section{References}

${ }^{1}$ Abrams, P H, British Fournal of Surgery, 1976, 63, 655.

2 Mitchell, J P, The Principles of Transurethral Resection and Haemostasis, p 173. Bristol, J Wright and Sons, 1972.

${ }^{3}$ Abrams, $\mathrm{P} \mathrm{H}$, Urologia Internationalis, in press.

* Boyarsky, S, and Labay, P, Ureter Dynamics, p 340. Baltimore, Williams and Wilkins, 1972.

Swinney, J, British Fournal of Urology, 1958, 30, 423.

${ }^{6}$ Hamilton-Stewart, H, British fournal of Urology, 1966, 38, 685.

7 Binard, J E C, and Zoedler, D, International Surgery, 1968, 50, 502.

(Accepted 6 September 1978)

\title{
Ethanol-induced increase in drug acetylation in man and isolated rat liver cells
}

\author{
HARALD OLSEN， JØRG MØRLAND
}

British Medical fournal, 1978, 2, 1260-1262

\section{Summary and conclusions}

Sixteen healthy volunteers took part in a cross-over study examining the effect of ethanol on the rate of sulphadimidine acetylation (blood ethanol concentration about $1 \mathrm{~g} / 1)$. In both rapid and slow acetylators the apparent half life of the drug decreased by about $20 \%$ after ethanol (mean reduction 39 SE $8 \mathrm{~min}$ ) and the amount of drug acetylated, measured in blood and urine, increased. In three slow acetylators the rate of acetylation in blood increased so noticeably after ethanol that they would otherwise have been classified as rapid acetylators. Suspensions of isolated rat liver cells showed an increase of about $30 \%$ in the rate of sulphadimidine acetylation after the addition of ethanol ( $2 \mathrm{~g} / 1)$.

Patients' usual alcohol consumption should be taken into account in determining their acetylator status. Department of Clinical Pharmacology, University Hospital,
Troms $\varnothing$ N-9012, Norway

HARALD OLSEN, MD, clinical pharmacologist

Institute of Medical Biology, University of Troms $\varnothing$, N-9001 Troms $\phi$, Norway

JØRG MØRLAND, MD, professor of pharmacology
Introduction

The acute interaction between ethanol and drugs usually leads to a decreased rate of drug metabolism. Both oxidation and conjugation of drugs with glucuronic acid, for example, may be inhibited by ethanol..$^{-x}$ Theoretically, however, ethanol could have the opposite effect on drug acetylation and enhance the speed of this conjugation reaction: ethanol is metabolised to yield acetate ${ }^{910}$ and may increase the concentration of acetyl coenzyme A (CoA), ${ }^{11}$ the acetate donor in the $N$-acetyltransferase reaction leading to acetylation of drugs. ${ }^{12}$ If a low concentration of acetyl CoA is rate-limiting in this reaction ethanol metabolism may increase the velocity by enhancing the formation of acetyl CoA. We decided to test this hypothesis. The activity of $\mathrm{N}$ acetyltransferase, which catalyses the transfer of acetyl groups to drugs such as hydrallazine, isoniazid, procainamide, and certain sulphonamides, is under genetic polymorphic control, and people may be classified as slow or rapid acetylators. ${ }^{13}$ Sulphadimidine is regarded as a model substance for acetylation, and we therefore used it in our studies.

\section{Materials and methods \\ IN-VIVO STUDIES ON MAN}

Sixteen healthy drug-free volunteers ( 6 women, 10 men) aged 18-36 years took part in a cross-over study. They were fasted overnight and at $8 \mathrm{am}$ received sulphadimidine by mouth $(10 \mathrm{mg} / \mathrm{kg})$. Two hours later they had a light breakfast, normal meals being allowed thereafter. Half the subjects received no further treatment, while the others had ethanol $\left(20^{\circ}{ }_{0} \mathrm{v} / \mathrm{v}\right.$ in fruit juice, $\left.0.73 \mathrm{~g} / \mathrm{kg}\right)$ two hours after taking the drug followed by hourly drinks of $0 \cdot 11 \mathrm{~g} / \mathrm{kg}$ until 10 hours after the 
drug. Venous blood samples $(10 \mathrm{ml})$ in heparinised tubes and occasionally urine samples were collected at two, four, six, eight, and 10 hours for measurement of drug, ethanol, and acetate concentrations. After centrifugation plasma was stored at $-20^{\circ} \mathrm{C}$ until analysed. One week later the experiment was repeated, the ethanol-treated and control groups being reversed. Thus each subject served as his or her own control.

\section{IN-VITRO STUDIES ON ISOLATED RAT LIVER CELLS}

Primary suspensions of isolated rat liver cells were prepared as described. ${ }^{1415}$ Primary suspensions from single rats contained $4 \cdot 66 \pm$ $0.34 \times 10^{9}$ viable parenchymal cells/l. One part of this suspension was incubated without ethanol and the other part with ethanol $(2 \mathrm{~g} / \mathrm{l})$ for four hours. Freshly made solutions of sulphadimidine were added at zero time. Portions of cell suspensions $(35 \mathrm{ml})$ were incubated in stoppered $1000 \mathrm{ml}$ flasks at $37^{\circ} \mathrm{C}$ in a shaker-incubator equilibrated at $\mathrm{PO}_{2} 100-130 \mathrm{~mm} \mathrm{Hg}$. Samples of medium $(5 \mathrm{ml})$ were taken for drug analysis at the time indicated after the cells had been centrifuged at $1600 \mathrm{~g}$ for one minute. At the end of the incubation period the numbers of viable cells (assessed by the trypan blue exclusion test) were reduced by $12 \pm 1 \%$ in both the control and the ethanol preparations.

\section{ANALYTICAL METHODS}

Ethanol concentrations were measured with an F42 Perkin Elmer head-space gas chromatograph. Blood acetate was determined by gas chromatography. ${ }^{16}$ Sulphadimidine was measured in duplicate in blood, urine, and cell media by Bratton and Marshall's method. ${ }^{17}$ This method measures unmetabolised (with a free $\mathrm{NH}_{2}$ group) and metabolised ( $N$-acetylated) sulphadimidine (sulphadimidine is thought to be metabolised mainly by acetylation ${ }^{18}$ ). With the BrattonMarshall method, should drug oxidation and glucuronidation occur to any appreciable degree the products are measured not as metabolites but as unmetabolised sulphadimidine. ${ }^{19}$ In separate experiments the addition of ethanol $(0.5-3.5 \mathrm{~g} / \mathrm{l})$ to blood or urine did not influence the measurements of sulphadimidine and acetylsulphadimidine in this assay. Furthermore, the assay was not influenced by adding blood from subjects with ethanol concentrations of $0 \cdot 8-1 \cdot 2 \mathrm{~g} / \mathrm{l}$.

Individual plasma sulphadimidine concentrations were plotted on a

TABLE I-Effect of ethanol on apparent half life of sulphadimidine in volunteers. Values are means $\pm S E$

\begin{tabular}{|c|c|c|c|c|}
\hline & \multicolumn{2}{|c|}{ Half life (min) } & \multicolumn{2}{|c|}{ Difference } \\
\hline & $\begin{array}{l}\text { Control } \\
\text { value }\end{array}$ & $\begin{array}{l}\text { After } \\
\text { ethanol }\end{array}$ & Min & $\%$ \\
\hline $\begin{array}{l}\text { Rapid acetylators }(n=9) \\
\text { Slow acetylators }(n=7)\end{array}$ & $\begin{array}{l}129 \div 4 \\
301 \pm 20\end{array}$ & $\begin{array}{c}99 \pm 3^{*} \\
250 \pm 22^{*}\end{array}$ & $\begin{array}{l}30 \pm 6 \\
51 \pm 16\end{array}$ & $\begin{array}{l}23 \cdot 3 \\
16 \cdot 9\end{array}$ \\
\hline
\end{tabular}

*P $<0.001$ compared with control value.

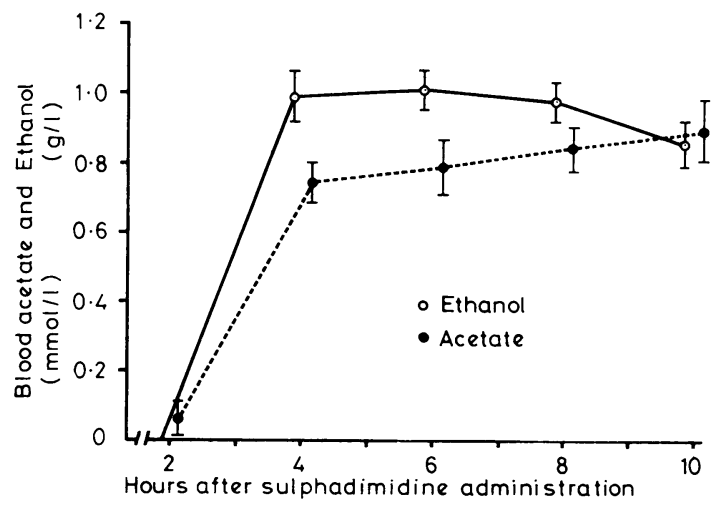

FIG 1-Mean ( $t$ SE) blood ethanol and acetate concentrations after oral dose of $0.73 \mathrm{~g}$ ethanol per $\mathrm{kg}$ at two hours followed by hourly doses of $0.11 \mathrm{~g} / \mathrm{kg}$ for rest of experiment in normal subjects.

Conversion: SI to traditional units-Blood acetate: $1 \mathrm{mmol} / 1 \approx 5.9 \mathrm{mg} / 100 \mathrm{ml}$.
TABLE II-Effect of ethanol on percentage of sulphadimidine acetylated. Values are means $\pm S E$

\begin{tabular}{|c|c|c|c|c|c|}
\hline & & & & \multicolumn{2}{|c|}{ Hours after sulphadimidine } \\
\hline & & & & 2 & 8 \\
\hline \multicolumn{6}{|c|}{ Slow acetylators $(n=7)$} \\
\hline $\begin{array}{l}\text { Control value } \\
\text { After ethanol }\end{array}$ & . & . & $\therefore$ & $\begin{array}{l}15 \cdot 3 \pm 1 \cdot 7 \\
17 \cdot 1 \pm 0 \cdot 7\end{array}$ & $\begin{array}{l}30 \cdot 0 \pm 1 \cdot 1 \\
36 \cdot 7 \pm 2 \cdot 9^{*}\end{array}$ \\
\hline \multicolumn{6}{|c|}{ Rapid acetylators $(n=9)$} \\
\hline $\begin{array}{l}\text { Control value } \\
\text { After ethanol }\end{array}$ & .. & 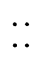 & . & $\begin{array}{l}44 \cdot 0 \pm 3 \cdot 4 \\
40 \cdot 2 \pm 2 \cdot 8\end{array}$ & $\begin{array}{l}79 \cdot 3 \pm 1 \cdot 9 \\
84 \cdot 7 \pm 1.9 \dagger\end{array}$ \\
\hline
\end{tabular}

$* P \leqslant 0.05$ compared with control value.
$+P<0.01$ compared with control value.

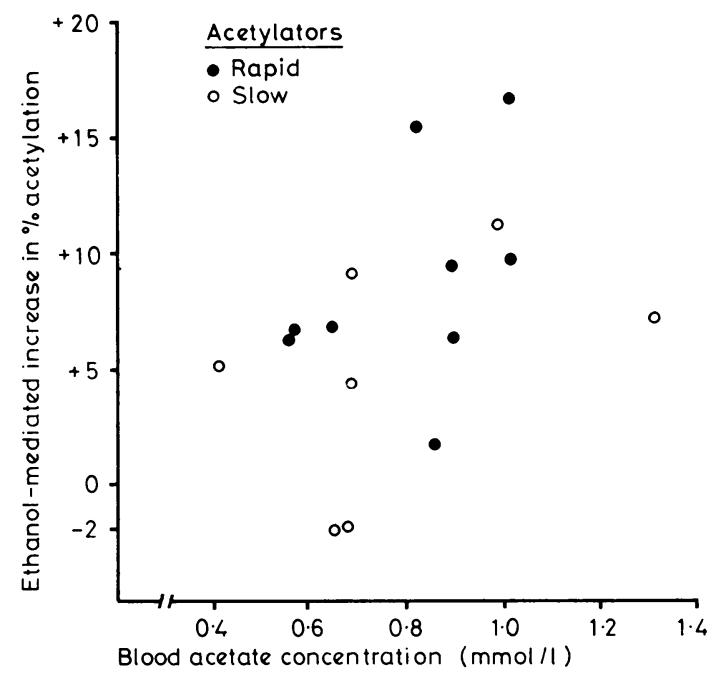

FIG 2-Ethanol-mediated increases in percentage sulphadimidine acetylation between two and eight hours. Increase - that is, increase in percentage acetylation in presence of ethanol minus increase in percentage acetylation without ethanol-is plotted against corresponding mean blood acetate concentrations in 16 different subjects.

Conversion: SI to traditional units-Blood acetate: $1 \mathrm{mmol} / 1 \approx 5.9 \mathrm{mg} / 100 \mathrm{ml}$.

logarithmic scale against time after administration. The "best-fit" straight line was drawn and the half life measured graphically. Renal drug clearance was calculated as the mean of clearances over the four-to-six-hour and six-to-eight-hour periods. Urinary excretion during each period was divided by the mean plasma concentration for that period calculated from the individual semilogarithmic plots of drug concentration.

Results obtained for each individual or cell suspension in the presence of ethanol were compared with results obtained without ethanol by Wilcoxon's test for paired samples. All results are given as means $\pm \mathrm{SE}$.

\section{Results}

IN-VIVO STUDIES ON MAN

Wide variations in rates of sulphadimidine metabolism were found among the 16 volunteers, nine of whom were classified as rapid acetylators and seven as slow acetylators. ${ }^{13}$ Individual sulphadimidine concentrations reached maximum values after two hours and then declined linearly in both the presence and the absence of ethanol. After they had taken ethanol the apparent half life of sulphadimidine decreased by about $20 \%$ in both the rapid and the slow acetylators (table I). This occurred in all participants except one, in whom no change was found. Ethanol administration was followed by relatively constant blood ethanol (about $1 \mathrm{~g} / \mathrm{l}$ ) and acetate (about $0.8 \mathrm{mmol} / 1$; $4.7 \mathrm{mg} / 100 \mathrm{ml}$ ) concentrations from two hours after intake (four hours after sulphadimidine) to the end of the experiment (fig 1).

The amount of sulphadimidine acetylated in blood increased with time in all experiments (table II). In the controls the increase in 
percentage acetylation between two and eight hours was 14.7 and 35.3 in the slow and rapid acetylators respectively (table II). These increases were greater $(\mathbf{P}<0.001)$ when ethanol was present $\left(19.6^{\circ}\right.$ and $44.5 \%$-table II). In three slow acetylators the percentage acetylation measured in blood at eight hours was increased so noticeably after ethanol that they would have been classified as rapid acetylators according to the criteria of Evans. ${ }^{13}$ The percentage acetylation measured in urine over the first eight hours of the experiment increased in the presence of ethanol by a mean of 13.3 in three subjects.

Ethanol did not change renal sulphadimidine clearance in three subjects $(11.42 \pm 3.73 \mathrm{ml} / \mathrm{min}$ without ethanol, $12.29 \pm 3.79 \mathrm{ml} / \mathrm{min}$ with ethanol), in whom the apparent sulphadimidine half lives were reduced by an average of $24 \cdot 1 \%$.

There were large variations between individuals in blood acetate concentrations after ethanol. When the mean concentration measured between four and 10 hours was plotted against the part of the increase in the amount of acetylated sulphadimidine that could be ascribed to ethanol (fig 2) some correlation was found $(r=0.49)$, which bordered on significance at the $5 \%$ level. An even poorer correlation $(r=0.09)$ was observed when the mean acetate concentrations were plotted against the relative decreases in apparent sulphadimidine half lives.

\section{IN-VITRO STUDIES ON ISOLATED RAT LIVER CELLS}

Ethanol $(2 \mathrm{~g} / \mathrm{l})$ decreased the half life of sulphadimidine in the primary suspensions of isolated rat liver cells by some $32^{\circ}$ (fig 3 ). This could not be explained by increased binding to liver cells of unmetabolised drug, since the administration of ethanol did not influence the recovery of "total" sulphadimidine (metabolised plus unmetabolised) in the samples.

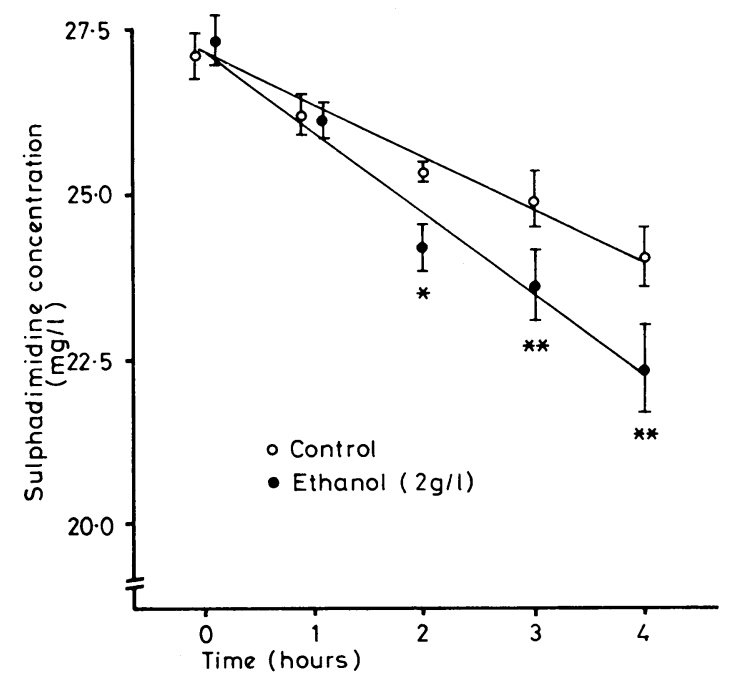

FIG 3-Effect of ethanol administration on sulphadimidine metabolism in suspensions of isolated rat liver cells. Results are means $( \pm S E)$ of seven experiments. Significance of difference from control values: ${ }^{* P}<0.05 ;{ }^{* *} P<0.01$.

\section{Discussion}

Our results show that acute ethanol intake is accompanied by a decrease in the apparent half life of sulphadimidine and by an increase in the amount of acetylated sulphadimidine in blood and urine. The individual plasma concentration curves (not shown) excluded any appreciable effect of ethanol on sulphadimidine absorption and distribution. Increased renal excretion of sulphadimidine after ethanol-due to alcohol diuresis, for example-was not found. These observations were all consistent with the view that ethanol increased the rate of drug acetylation.

The findings were supported by experiments on suspensions of isolated rat liver cells. In this system the sulphadimidine concentration could decrease by metabolism only. As shown in fig 3, ethanol decreased the apparent half life of sulphadimidine in the liver cell suspensions. The precise mechanism is speculative. The magnitude of the correlation between blood acetate concentrations and the relative change in sulphadimidine acetylation may argue against a simple relation between ethanol oxidation and drug acetylation. On the other hand, the hepatic concentration of acetyl CoA may be relevant. Since we cannot measure acetyl CoA concentrations in the intact liver further in-vitro experiments are being carried out to clarify the mechanism underlying the effect of ethanol on sulphadimidine acetylation.

To our knowledge this is the first report of this type of interaction between ethanol and sulphádimidine acetylation. In a previous study the metabolism of sulphanilamide in rats appeared to be unchanged by ethanol. ${ }^{20}$ In that study, however, drug and metabolites were measured only in urine and sulphanilamide half life was not measured. Furthermore, the mode of administration of drug and alcohol differed appreciably from that in our series. In a study on rats given isoniazid the excretion of $\mathrm{N}$-acetylisoniazid increased in the presence of ethanol. ${ }^{21}$ In another study the half life of isoniazid was decreased in the presence of ethanol in two test subjects. ${ }^{22}$ Since sulphadimidine is regarded as a model substance, acetylation of other drugs (isoniazid, hydrallazine, procainamide), and indeed other exogenous compounds, may also be influenced by ethanol. If so, ethanol consumption might reduce blood concentrations of drugs that are metabolised by acetylation. Furthermore, the pattern of metabolites could change noticeably for drugs with alternative metabolic pathways. In such cases ethanol might reduce drug oxidation and glucuronidation but increase acetylation. One might also speculate whether ethanol could increase the toxicity of foreign compounds, since this may be linked to the rate of acetylation. ${ }^{23}$

Finally, it may be important to take a patient's usual alcohol consumption into account in determining his acetylator status.

This study has been supported in part by grants from the Norwegian Research Council for Science and the Humanities.

Requests for reprints should be addressed to: Professor Jorg Mørland, Institute of Medical Biology, University of Tromsø, N-9001 Tromsø, Norway.

\section{References}

1 Nelson, E, Nature, 1962, 193, 76.

2 Waris, E, Annales Medicinae Experimentalis et Biologiae Fenniae, 1963, 41, 45.

${ }^{3}$ Soehring, K, and Schüppel, R, Deutsche medizinische Wochenschrift, 1966, 91, 1892

4 Schüppel, R, Naunyn-Schmiedeberg's Archiv für experimentelle Pathologie und Pharmakologie, 1967, 257, 60.

${ }^{5}$ Rubin, E, and Lieber, C S, Science, 1968, 162, 690.

6 Rubin, E, et al, American fournal of Medicine, 1970, 49, 801.

${ }^{7}$ Hänninen, O, and Alanen, K, Biochemical Pharmacology, 1966, 15, 1465

${ }^{8}$ Moldeus, P, Vadi, H, and Berggren, M, Acta Pharmacologica et Toxicologica, 1976, 39, 17

9 Forsander, O, and Räihä, N, Fournal of Biological Chemistry, 1960, 235, 34

10 Lundquist, F, et al, fournal of Clinical Investigation, 1962, 41, 955.

11 Forsander, O, and Lindros, K, Acta Chemica Scandinavica, 1967, 21, 2568.

12 Weber, W W, Handbuch der experimentellen Pharmakologie, 1971, 28, 564

13 Evans, D A P, fournal of Medical Genetics, 1969, 6, 405.

14 Berry, M N, and Friend, D S, fournal of Cell Biology, 1969, 43, 506.

${ }_{15}$ Morland, J, and Olsen, H, Drug Metabolism and Disposition, 1977, 5, 511.

${ }^{16}$ Ottenstein, D M, and Bartley, D A, fournal of Chromatographic Science, $1971,9,673$.

17 Bratton, A C, and Marshall, E K, fournal of Biological Chemistry, 1939, 18, 537.

${ }^{18}$ Williams, R T, Detoxication Mechanisms, 2nd edn. London, Chapman and Hill, 1959.

19 Bevill, R F, et al, American fournal of Veterinary Research, 1977, 38, 973.

${ }^{20}$ Schüppel, R, Naunyn-Schmiedeberg's Archiv für experimentelle Pathologie und Pharmakologie, 1969, 265, 233.

${ }^{21}$ Thomas, B H, and Solomonraj, G, Fcurnal of Pharmaceutical Sciences, $1977,66,1322$.

22 Lester, D, Quarterly fournal of Studies on Alcohol, 1964, 25, 541.

${ }^{23}$ Mitchell, J R, et al, Clinical Pharmacology and Therapeutics, 1975, 18, 70. 